\title{
Esej naukowy jako podstawowa forma wypowiedzi studenta - różnice między brytyjskim a polskim systemem edukacji wyższej w podejśsiu do krótkich prac pisemnych
}

\author{
Maciej Hacaga \\ Stacjonarne Studia Doktoranckie, Wydział Bezpieczeństwa Narodowego, \\ Akademia Sztuki Wojennej
}

\begin{abstract}
Współczesna gospodarka, oparta na usługach, wymaga od absolwentów szkół wyższych umiejętności sprawnego komunikowania się nie tylko w mowie, lecz także pisemnie. W polskim szkolnictwie wyższym, poza przygotowaniem prac dyplomowych, obszarowi temu poświęca się niewiele zainteresowania. Dla odróżnienia, w wyższym szkolnictwie brytyjskim esej stanowi jedno z podstawowych narzędzi nauczania i sprawdzania wiedzy. W artykule przedstawiono formy wykorzystania eseju w London School of Economics. Następnie przedstawiono problemy, z którymi jest związane jego potencjalne upowszechnienie w Polsce oraz sposoby ich rozwiązania.
\end{abstract}

Słowa kluczowe: prace pisemne, esej, metody nauczania, rozwój umiejętności pisarskich, szkolnictwo wyższe

\section{Wprowadzenie}

Biorąc pod uwagę pozytywne wartości związane z esejem akademickim jako narzędziem edukacyjnym, jest zaskakujące, jak rzadko jest w Polsce spotykana ta forma nauczania i sprawdzania wiedzy. Tymczasem esej ma dobrze ugruntowaną, centralną pozycję w szkolnictwie wyższym byłego imperium brytyjskiego, którą zawdzięcza kilku powodom. Po pierwsze, ma charakter wyjaśniający i/lub argumentacyjny, oparty na danych i teoriach. Po drugie, wypływa z założenia, że 
wymiana idei jest istotną kwestią dla współczesnego dyskursu publicznego. Po trzecie, jego celem jest przekonanie czytelnika do argumentacji autora. W połączeniu, te elementy czynią go narzędziem, które pozwala ocenić stopień zrozumienia materiału i na tej podstawie zróżnicować studentów (Andrews, 2003, s. 120). Jego szczególna, humanistyczna rola wynika z braku konkretnie sformalizowanego celu, gdyż mieści się on między konwencjami czysto praktycznymi (jak raporty biznesowe) a konwencjami czysto kreatywnymi (jak twórczość literacka). To zaś w odróżnieniu od treningu zawodowego - jest funkcją ogólnego charakteru studiów, przygotowującego do udziału w dyskursie publicznym (Womack, 1993, s. 44).

Zaobserwowane różnice w podejściu do eseju jako narzędzia edukacji wyższej w Polsce i Wielkiej Brytanii są główną motywacją niniejszego artykułu. Powstał na bazie moich doświadczeń wyniesionych ze studiów magisterskich, odbytych w London School of Economics and Political Science (LSE). W trakcie rocznych studiów magisterskich w Londynie napisałem 12 esejów w ramach pracy zadanej przez wykładowców, 30-40 esejów próbnych przed sesją oraz 11 esejów podczas sesji egzaminacyjnej. Daje to min. 50 esejów przygotowanych w tym czasie. Dla porównania, w trakcie trzech lat studiów licencjackich na Uniwersytecie Warszawskim napisałem około 12 esejów.

W niniejszym artykule chcę się podzielić wiadomościami na temat tego, jak wygląda wykorzystanie eseju w systemie brytyjskim na przykładzie LSE. Ponadto, podejmuję krótką polemikę z polskimi głosami w debacie nad wartością eseju. Tam, gdzie tylko jest to możliwe, staram się stosować perspektywę porównawczą, aby uchwycić różnice między oboma systemami edukacji. Czynię to z zastrzeżeniem, że moja percepcja jest ograniczona i wynika z relatywnie krótkiego okresu pobytu w Londynie.

\section{Identyfikacja problemu}

Wydaje się, że w Polsce tworzenie wypowiedzi pisemnych (pomijając prace dyplomowe) jest traktowane z pewnym lekceważeniem. Ilustracją takiej postawy jest sytuacja, jaka spotkała autora tego artykułu. W trakcie studiów na Uniwersytecie Warszawskim zapytał on jednego z wykładowców o zajęcia dotyczące rozwoju umiejętności tworzenia tekstów akademickich, miał bowiem poczucie znaczących braków w tym zakresie. W odpowiedzi usłyszał, że tego typu umiejętności powinny zostać wyniesione ze szkoły średniej, są wszakże potwierdzone maturą, która stanowi warunek wstępny przyjęcia na studia wyższe. Zdaje się to stanowić nieświadome potwierdzenie obecnego w Polsce podejścia, które głosi, że „[anglosaski esej] Bliski jest raczej polskiej szkolnej rozprawce, którą uczniowie opanowują bez większych trudności"(Kaliszewska, 2010, s. 128). 
Tymczasem absolwenci polskich szkół wyższych mają trudności w komunikacji, które przeczą takiemu tokowi rozumowania. Jeden z przykładów to orzeczenia sędziowskie, które bardzo często: 1) są niezrozumiałe, 2) zawierają błędy językowe, 3) kopiują inne orzeczenia. Jak zatem twierdzi prof. Ewa Łętowska, jeden z czołowych przedstawicieli polskich nauk prawnych: „Problem jest systemowy i dotyczy nie tylko sędziów. Nagminnie widzę, że pisać nie potrafią także doktoranci, nawet habilitanci" (za: Słowik, 2016). Problemy z wypowiedziami pisemnymi odnotowuje się także w przypadku studentów dziennikarstwa. W tym wypadku jest postulowane poszukiwanie źródeł problemów w szkołach podstawowych, które dalej narastają w szkołach licealnych (Kaczmarczyk, 2012). Nie dziwi zatem, że już w 2010 r. odnotowano, iż po tworzone na zlecenie dokumenty zgłasza się coraz więcej osób, które nie potrafią samodzielnie napisać pracy (Przybyłowska, Krzewińska, 2012, s. 332). W Polsce zwracano uwagę na niepełne wykorzystanie tej metody w sposób dosłowny: „Pozycja eseju w dydaktyce akademickiej nie jest oczywista. Istnieje on z nazwy, natomiast nie jest ani doceniony, ani przemyślany, ani odpowiednio eksploatowany, jak wynika ze zgromadzonej polskiej literatury przedmiotu" (Kaliszewska, 2010, s. 135). W związku z tym postulowano wprowadzenie nauki pisania dla studentów kierunków związanych z ochroną środowiska (Maciejowska, 2009) oraz pedagogów (Kaliszewska, 2010).

\section{Eseje w London School of Economics and Political Science}

Od strony praktycznej eseje pełnią co najmniej dwojaką rolę w LSE. Eseje są w niej wykorzystywane zarówno w trakcie roku szkolnego (jako środek nauczania), jak i podczas sesji egzaminacyjnej (jako forma sprawdzania wiedzy). Ponieważ są one kluczowym narzędziem formalnej komunikacji pracy między studentami a wykładowcami, LSE zapewnia różnego rodzaju kursy dokształcające studentów/ ki w tym zakresie.

\section{Przygotowanie do pisania esejów}

Różnice pomiędzy systemami edukacji uwidaczniają się już na początkowym etapie, czyli wsparciu ze strony uczelni $\mathrm{w}$ rozwijanie umiejętności tworzenia prac pisemnych. W ramach tego typu działań LSE prowadzi kursy pt. Academic Writing Skills ${ }^{1}$. Jest ich kilka, a zainteresowani słuchacze są przyporządkowywani

1 W USA wszyscy studenci podejmujący naukę na poziomie licencjackim są zobowiązani do zaliczenia kursu podnoszącego ich umiejętności w zakresie tworzenia wypowiedzi pisemnych (Andrews, 2003, s. 1). 
na podstawie wydziału, na którym studiują. Przykładowo, jeden z nich jest przeznaczony dla studentów wydziałów Geografii i Środowiska, Rozwoju Międzynarodowego oraz Filozofii, Logiki i Metod Naukowych (LSE, 2016f), a inny dla studentów wydziałów Historii Gospodarczej, Historii Międzynarodowej, Instytutu Europejskiego czy Stosunków Międzynarodowych (LSE, 2016e).

Tego typu kurs nie jest, co prawda, obowiązkowy, ale jest co najmniej zalecany przez LSE tym studentom, dla których język angielski nie jest językiem natywnym. Jak stanowi opis kursu, efektami kształcenia są (LSE, 2016e): 1) znajomość konwencji piśmiennictwa naukowego, 2) poprawienie dokładności, klarowności oraz spójności wypowiedzi pisemnych, 3) przećwiczenie czytelnej organizacji tekstów i akapitów, 4) rozszerzenie zakresu wypowiedzi leksykalnych i gramatycznych, 5) zdolność oceny własnych wypowiedzi pisemnych oraz 6) zwiększenie płynności i pewności pisania.

Oddzielne kursy poświęcone tworzeniu prac pisemnych na poziomie studiów magisterskich prowadzą m.in. Wydział Zarządzania (LSE, 2016i), Wydział Polityki Społecznej (LSE, 2016m; LSE, 20161; LSE, 2016k; LSE, 2016n) oraz Wydział Historii Gospodarczej (LSE, 2016a). Na gruncie polskim postuluje się utworzenie tego typu przedmiotu, zarówno pogłębiającego znajomość języka jak i uzupełniającego braki w zakresie językowych kompetencji (Kaliszewska, 2010, s. 141).

\section{Esej jako forma nauczania}

W trakcie moich studiów główną formą komunikacji zdobywanej wiedzy były tzw. formative essays (które będę dalej nazywał esejami formującymi). „Formative” w tym przypadku oznaczało, iż chociaż eseje te były oceniane, to oceny te nie były oficjalne i nigdzie nie były odnotowywane. W ramach programu, który studiował autor tego tekstu, jedynie eseje napisane w trakcie sesji dostarczały końcowych ocen z odbytych kursów. Dla każdego przedmiotu rocznego student miał przygotować trzy, maksymalnie cztery eseje formujące. Przedmioty jednosemestralne wymagały przygotowania dwóch wypowiedzi pisemnych. Chociaż nie były one obowiązkowe, to zdecydowana większość studentów je przygotowywała, traktując jako przygotowanie do sesji.

Jak wskazywali w swoich sylabusach wykładowcy, chociaż eseje tego typu nie wchodziły w skład oceny końcowej z danego przedmiotu, niosły za sobą inne wartości dodane. Po pierwsze, są dobrym narzędziem do studiowania literatury przedmiotu. Po drugie, służą jako dobry wskaźnik rozwoju zarówno wiedzy, jak i umiejętności komunikacyjnych studentów. Wreszcie, w przypadku braku innych publikacji, mogą one służyć jako dokumenty wspierające aplikacje doktoranckie bądź zawodowe. 
Trzeba przy tym zauważyć, że różne wydziały w różny sposób podchodzą do tematu. W niektórych (jak np. na Wydziale Historii Gospodarczej czy Wydziale Historii Międzynarodowej) eseje formujące w ogóle nie liczą się do oceny z przedmiotu i mają charakter jedynie edukacyjno-przygotowawczy. W innych, jak np. na Wydziale Stosunków Międzynarodowych, dużo zależy od przedmiotu. Można znaleźć takie, gdzie ocena z przedmiotu jest wystawiana na podstawie eseju formującego (LSE, 2016d), takie, w którym ocena końcowa jest złożona z ocen eseju formującego oraz eseju egzaminacyjnego (Lawson, 2015), oraz takie, gdzie ocena jest wystawiana tylko i wyłącznie na podstawie eseju egzaminacyjnego (LSE, 2016c). Jeszcze inaczej podchodzi się do tej kwestii na Wydziale Zarządzania. W jego ofercie znajdziemy przedmioty, gdzie ocena jest: 1) wypadkową esejów formujących, egzaminacyjnych i prezentacji (LSE, 2016g); 2) wypadkową eseju formującego i projektu (LSE, 2016j) oraz 3) średnią z klasycznych esejów egzaminacyjnych (LSE, 2016h). W tabeli 1 przedstawiono te różnice na podstawie trzech wybranych przedmiotów z trzech wydziałów. Warto zwrócić uwagę, że niezależnie od tego, czy eseje pisane w trakcie roku akademickiego są oceniane, czy nie, ich ogólna liczba pozostaje na tym samym poziomie 6 esejów. W przypadku przedmiotu trwającego jeden semestr liczba esejów wynosi 3.

Tabela 1. Porównanie wybranych kursów na poziomie magisterskim na LSE pod względem liczby esejów

\begin{tabular}{|l|c|c|c|}
\hline Wyszczególnienie & $\begin{array}{c}\text { IR436 Theories of } \\
\text { International Relations }\end{array}$ & $\begin{array}{c}\text { EH483 The } \\
\text { Development and } \\
\text { Integration of the } \\
\text { World Economy in the } \\
19^{\text {th }} \text { and 20 } 0^{\text {th }} \text { Centuries }\end{array}$ & $\begin{array}{c}\text { MG404 Behavioural } \\
\text { Fundamentals for } \\
\text { Marketing and } \\
\text { Management }\end{array}$ \\
\hline Długość kursu & roczny & roczny & semestralny \\
\hline Poziom & magisterski & magisterski & magisterski \\
\hline Wydział & $\begin{array}{c}\text { Wydział Stosunków } \\
\text { Międzynarodowych }\end{array}$ & $\begin{array}{c}\text { Wydział Historii } \\
\text { Gospodarczej }\end{array}$ & Wydział Zarządzania \\
\hline Eseje formujące & 3 & 3 & $0^{a}$ \\
\hline Eseje oceniane & 1 & 0 & 1 \\
\hline $\begin{array}{l}\text { Eseje } \\
\text { egzaminacyjne }\end{array}$ & 6 & 3 & 3 \\
\hline Razem & Lawson, 2015 & LSE, 2016b & LSE, 2016g \\
\hline Źródło & 2 & kong. & \\
\hline
\end{tabular}

a Student przygotowuje szkic (draft) eseju, który jest później konsultowany z wykładowcą.

Źródło: Lawson, 2015; LSE, 2016b; LSE, 2016 g. 
Szczególnie instruktywny jest przykład kursu IR436 Theories of International Relations. Wydział Stosunków Międzynarodowych LSE uchodzi za jeden z najlepszych na świecie w tej dyscyplinie, poza granicami USA (Gramer, 2015). Znajduje to odzwierciedlenie $w$ kursie dotyczącym podstaw teoretycznych tego przedmiotu i w tym, jak eseje są stosowane, by zapewnić odpowiednio wysoki poziom wykształcenia. Po pierwsze, student jest zobowiązany do napisania trzech esejów formujących, które w logicznej kolejności dotyczą następujących zagadnień: 1) budowanie teorii w stosunkach międzynarodowych i wytyczanie obszaru tej dyscypliny, 2) teorie głównego nurtu w stosunkach międzynarodowych, 3) teorie krytyczne. Następnie przygotowuje esej liczący 4000 słów, przy czym może wykorzystać swoje wcześniejsze eseje. Ocena z tego eseju stanowi 50\% oceny $z$ kursu. Wreszcie, podczas sesji, student pisze dwa eseje egzaminacyjne (Lawson, 2015, s. 4). Taka organizacja kursu powoduje, że student nie może nie przyswoić materiału kluczowego dla całego programu studiów magisterskich w obszarze stosunków międzynarodowych ${ }^{2}$.

Jak widać, studenci LSE są obciążeni dość wysoką liczbą prac pisemnych. Niemniej jest ona kompensowana niższą, w porównaniu do Polski, liczbą przedmiotów. Zdecydowana większość programów studiów magisterskich wymaga zebrania czterech jednostek (tzw. units). Przedmiot semestralny jest liczony jako pół jednostki, roczny jako jedna, praca magisterska również jako jedna (dużo rzadziej jako pół, choć i to się zdarza). Proste przeliczenie wskazuje, że (po odjęciu pracy magisterskiej) student może się zarejestrować na maksymalnie sześć przedmiotów semestralnych oraz trzy roczne, ew. ich kombinację. Ograniczenie obciążenia intelektualnego jest niezbędne, bowiem wśród czynników wpływających na jakość pracy pisemnej jest ilość czasu poświęcanego na esej, co wpływa na liczbę odniesień do pozycji książ̇kowych, liczbę cytowań oraz stopień oparcia eseju na badaniach własnych (Norton, 1990). Tymczasem, przeciętny słuchacz studiów magisterskich $\mathrm{w}$ Polsce $\mathrm{w}$ ciągu jednego tylko semestru ma zwykle do zdania więcej niż sześć przedmiotów (powyżej 12 przedmiotów rocznie). Trudno zatem wymagać od polskich studentów, by byli w stanie na każdy z nich przygotować po co najmniej trzy dobrze przygotowane prace pisemne.

Najważniejsze, z perspektywy rozwoju warsztatu autora tego tekstu, były informacje zwrotne, jakie dostał on do swoich prac. Otrzymywaliśmy je w okresie 2-3 tygodni od wysłania esejów, najczęściej w formie elektronicznej. Niektórzy wykładowcy wymagali osobistego odebrania formularza informacji zwrotnej, co

2 Warto się przyjrzeć temu dokumentowi (Lawson, 2015), bowiem rzadko czołowe uczelnie udostępniają tak rozbudowane sylabusy, obejmujące opis kursu, bibliografię oraz przykładowe pytania egzaminacyjne. 
pozwalało im na przekazanie dodatkowo uwag ustnych. Taka informacja zwrotna była swego rodzaju analizą pracy pisemnej, podzieloną na następujące aspekty: 1) koncentracja na temacie eseju, 2) struktura i spójność tekstu, 3) głębokość analizy oraz jakość przedstawionej argumentacji, 4) poziom użytego języka, 5) znajomość literatury. Dla porównania, autor nie otrzymał żadnej informacji zwrotnej do choćby jednego ze swoich esejów na Uniwersytecie Warszawskim. Jedyną formą komunikacji ze strony wykładowców były oceny. Tylko że ocena, niezależnie, czy wysoka, czy niska, nic nie mówi studentowi o tym, co należałoby poprawić, a co było właściwie napisane.

Na gruncie polskim I. Maciejowska (2009, s. 97) postuluje przedstawianie: „studentom zebranych dla całej grupy uwag i komentarzy na temat ich wcześniejszych prac i/lub uwag zebranych w latach poprzednich wraz, co bardzo ważne, $\mathrm{z}$ anonimowymi przykładami”. Anonimowość jest niezwykle ważna w takiej sytuacji, ale zbiorowa informacja zwrotna poszczególnym studentom na niewiele się zda. Tym, co w bezpośredni sposób przyczynia się do rozwoju studenta, to kontakt z nauczycielem i osobiste wyjaśnienia. Jednakże zbytnie obciążenie wykładowców (o czym będzie mowa dalej) znacząco ogranicza możliwości wprowadzenia takiego rozwiązania.

\section{Esej jako forma zaliczenia}

W moim przypadku esej był stosowany nie tylko jako forma nauki, lecz także sprawdzania nabytej wiedzy. W trakcie sesji wieńczącej roczny program studiów magisterskich odbyłem trzy trzygodzinne egzaminy, w których trakcie byłem zobowiązany do napisania trzech esejów. Ponadto, zaliczyłem jeden dwugodzinny egzamin, w którego trakcie napisałem dwa eseje. Ocena końcowa z każdego przedmiotu stanowiła średnią arytmetyczną z poszczególnych esejów.

Wydaje się, że taka metoda sprawdzania wiedzy zasługuje na uznanie z dwóch zasadniczych względów. Po pierwsze, wymaga pracy pod presją czasu, z czym każdy człowiek spotyka się w dzisiejszym zglobalizowanym świecie. Dla młodych studentów jest więc to dobra „szkoła życia” przed wejściem na rynek pracy, który oczekuje dzisiaj od absolwentów szybkich i jednocześnie poprawnych analiz. Po drugie, jest o bardziej wymagająca intelektualnie niż zwykłe zapamiętanie informacji potrzebnych do zdania egzaminu w formie testu. Wymaga bowiem nie tylko wiedzy teoretycznej oraz znajomości literatury, lecz także umiejętności własnego myślenia oraz posiadania choćby podstawowych informacji o wydarzeniach i procesach czy danych. Od studenta oczekuje się zatem, że, działając pod presją czasu, dokona szybkiej i - co ważne - właściwej i jednoczesnej aplikacji tych wszystkich elementów do zadanego problemu. 


\section{Wyzwania związane z tworzeniem esejów}

We wcześniej przytaczanej polskiej literaturze wskazuje się nie tylko wartość dodaną, lecz także wyzwania płynące z zastosowania esejów jako metody nauczania. W tej części artykułu postaram się odnieść do przedstawianych obaw oraz zaprezentować, jak można zapobiec ich materializacji na podstawie doświadczeń systemu brytyjskiego.

Jako pierwsze ryzyko wskazuje się upowszechnienie nowoczesnych technologii. Konkretniej rzecz ujmując, tego, że rozwój Internetu doprowadził nie tylko do plagi plagiatów, lecz także grozi powstaniem „baz esejów” (Maciejowska, 2009, s. 96; Kaliszewska, 2010, s. 128). Tego typu patologii można zapobiec, stosując dwa sposoby

Po pierwsze, w LSE tematy esejów praktycznie się nie powtarzają. Jeśli już dochodzi do takiej sytuacji, to ma to miejsce w odstępach kilkuletnich. Oczywiście, nie sposób jest przygotować zestaw zupełnie nowych tematów co rok. Niemniej, często wystarczy nieznaczne ich zmodyfikowanie, aby skutecznie uniemożliwić wykorzystanie przygotowanej przez kogoś innego pracy. Przykładem niech będzie zmiana łącznika w zdaniu „Przedyskutuj wybrane zagadnienie na podstawie paradygmatu $y$ albo $z$ ”, co skutkuje powstaniem zdania „Przedyskutuj wybrane zagadnienie na podstawie paradygmatu $y$ oraz z". Inną formą modyfikacji może być zmiana zakresu eseju, np. z geograficznego na czasowy. Może to przybrać formę zmiany ze „Wzrost gospodarczy państw Azji Wschodniej w świetle teorii $x$ po 1945 r.” na „Porównaj wzrost gospodarczy dwóch wybranych państw Europy Środkowej w świetle teorii $x$ po 1990 r.". Takie, teoretycznie niewielkie, zmiany zmuszają studenta do sięgnięcia po inną literaturę i uniemożliwiają plagiat.

Po drugie, w systemie brytyjskim mają miejsce bardzo ostre kary za wykorzystanie cudzej pracy. Jest to jednoznacznie określone jako najpoważniejsze wykroczenie w świecie akademickim. W przypadku wykrycia, minimalną sankcją jest niezaliczenie przedmiotu, zaś maksymalną - odmowa przyznania tytułu zawodowego bądź naukowego (Lawson, 2015, s. 5). Tymczasem w Polsce problem ten dotyczy nie tylko studentów, lecz także kadry akademickiej: „Analiza przypadków ujawnionych plagiatów wśród nauczycieli uczelni wyższych wykazuje, że najczęściej w przypadku popełnienia plagiatu przez nauczycieli akademickich orzekana jest jako kara dyscyplinarna - kara nagany. [...] Niezwykle rzadko orzekana jest kara dyscyplinarna pozbawienia prawa wykonywania zawodu nauczyciela akademickiego" (Sieńczyło-Chlabicz, 2010, s. 146).

Na marginesie dyskusji o tematach esejów trzeba zauważyć jeszcze jedną różnicę między systemem brytyjskim a systemem polskim, która wpływa na 
aktywną bądź pasywną postawę studentów wobec prac pisemnych. Otóż w Polsce, z bardzo nielicznymi wyjątkami, studenci mają z góry narzucony wybór przedmiotów na swoim kierunku. Jednocześnie, kiedy już przychodzi do napisania pracy semestralnej, nierzadko dostają komunikat od wykładowcy „Niech Pan/ /Pani wybierze sobie jakiś temat”. Inaczej mówiąc, student jest zmuszany do nauki przedmiotu, którym niekoniecznie jest zainteresowany, ale w jego ramach ma możliwość wybrania zagadnienia, o którym będzie pisał. Moje doświadczenie z Wielkiej Brytanii jest inne. Student ma możliwość wyboru zdecydowanej większości kursów w ramach kierunku studiów, ale lista tematów, na które formułuje swoje wypowiedzi pisemne, jest z góry narzucona przez wykładowcę, specjalistę $\mathrm{w}$ ramach danego przedmiotu.

Kolejna kwestia dotyczy aspektów technicznych pracy. Na gruncie polskim postuluje się, że wykładowca powinien wyznaczać bardzo konkretne normy edytorskie czy sposób wizualizacji danych w esejach (Maciejowska, 2009, s. 96) ${ }^{3}$. Są one istotnie niezbędne na poziomie licencjackim i dowodzą wręcz konieczności wprowadzenia zajęć $z$ pisania dla polskich studentów na początkowych etapach edukacji wyższej. Dla odróżnienia, na poziomie studiów magisterskich wykładowcy LSE wydają się przywiązywać mniejszą wagę do tego, jak praca ma wyglądać, np. ograniczając się do jedynie uwagi, że esej powinien być wydrukowany na kartce formatu A4 z podwójną interlinią. Zwracają przy tym uwagę, że esej musi zawierać bibliografię oraz przypisy, nie wskazując jednocześnie żadnego konkretnego stylu (Lawson, 2015, s. 4).

Akcent w LSE jest położony nieco w innym miejscu, a mianowicie na długość esejów oraz sposób jej wyznaczania. Prace pisemne są bowiem ograniczone ilościowo nie „od dołu” (jak to zwykle w Polsce bywa), ale „od góry”. Długość tych, które napisał autor tego tekstu, była określona na maksymalnie 1500-2500 słów (w zależności od przedmiotu) ${ }^{4}$, co przekładało się na 4-5 stron tekstu bez przypisów i bibliografii. Dla porównania, w Polsce spotykałem się z wymaganiami „Co najmniej 8-10 stron”. Wprowadzenie słów jako sposobu pomiaru długości powodowało, że stosowane sztuczki w postaci zmiany czcionki, interlinii czy marginesów w celu sztucznego wydłużenia tekstu traciły sens. Ograniczenie długości

3 I. Maciejowska wymienia ustalenia m.in. na temat „rozmiaru marginesów, czcionki i odstępów pomiędzy linijkami [...], zakresu liczby stron i sposobu numeracji stron (bardzo pomaga, gdy luźne kartki się rozsypią), sposobu przedstawiania wykresów (wraz z informacją, że są preferowane w stosunku do tabel) oraz opisu tabel, wykresów, rysunków i zdjęć, sposobu odwoływania się do literatury (przypomnienie, że w ogóle wszystkie dane liczbowe, cytaty, zdjęcia itd. muszą mieć podane źródło!), konieczności wyjaśniania akronimów zastosowanych w tekście [...]”.

4 Należy zauważyć, że są również zadawane eseje dłuższe, liczące 4000-6000 słów. Niemniej, w takim przypadku albo ogólna liczba esejów w danym przedmiocie jest zmniejszana, albo studenci mają prawo wykorzystać elementy wcześniejszych prac. 
wypowiedzi powoduje, że student uczy się pisać zwięźle i nie „produkować” nadmiaru treści. Zresztą należałoby zapytać, czy słuchacz studiów magisterskich lub licencjackich jest w stanie napisać kilkanaście stron prawdziwie autorskiej wypowiedzi. Czy zadawanie zbyt długich prac pisemnych nie powoduje, iż stają się one jedynie reprodukcją bądź parafrazą cudzej pracy?

Kolejny podnoszony w Polsce zarzut jest taki, że esej anglojęzyczny może być stosowany w wybranych tylko dziedzinach nauki, odznaczających się potrzebą wysokiego sformalizowania wywodu. Dotyczy to studiów prawniczych, historycznych, psychologicznych, socjologicznych i teologicznych. Tymczasem w pozostałych gałęziach studiów humanistycznych oraz pedagogicznych jest zapotrzebowanie na eseje formalne i nieformalne (Kaliszewska, 2010, s. 128). Autor niniejszego artykułu swoje wykształcenie uzyskał na polu nauk społecznych i historycznych, zatem nie może się wypowiadać na temat innych nauk. Niemniej jednak wydaje się, że M. Kaliszewska umniejsza rolę eseju formalnego. Esej naukowy, niezależnie od dziedziny, powinien mieć strukturę zbliżoną do tej, która jest wymagana od studentów w systemie brytyjskim. Charakteryzuje go wyartykułowanie pytania badawczego, ugruntowanie zarówno teoretyczne, jak i w literaturze przedmiotu, odpowiedni podział na paragrafy oraz przeprowadzony klarownie wywód logiczny, prowadzący do konkluzji i (potencjalnego) wkładu w daną dziedzinę. Dlatego, nawet jeśli w niektórych dyscyplinach występuje zapotrzebowanie na eseje nieformalne i/lub o luźniejszej strukturze, to sformalizowany esej typu angielskiego wydaje się znajdować swoje zastosowanie w każdej pracy naukowej.

Należy także zwrócić uwagę na obciążenie czasowe wykładowców. I. Maciejowska (2009, s. 96) zwraca uwagę, że sprawdzenie pracy studenta liczącej 6-8 stron wymaga poświęcenia co najmniej 30 minut, co przy dużych grupach kumuluje dużą ilość czasu. To zaś kieruje rozważania w kierunku stosunku liczby studentów do liczby wykładowców. Na czołowych brytyjskich uczelniach relacja ta waha się od 10:1 do 12:1 (The Complete University Guide, 2017). Stosunek liczby studentów do liczby nauczycieli akademickich na polskich uczelniach na przełomie pierwszej i drugiej dekady XXI w. wynosił 21:1 na kierunkach społecznych, 18:1 na kierunkach technicznych, 16:1 na kierunkach humanistycznych, 15:1 na kierunkach przyrodniczych oraz 14:1 na kierunkach ścisłych (SMG/KRC Poland Media S.A., 2010, rysunek 6). Oznacza to, wskaźnik wskaźnik student-staff ratio wynosi w LSE 50\% typowych polskich wartości w przypadku kierunków społecznych i 63-75\% w przypadku kierunków humanistycznych. Trudno zatem wymagać od polskiej kadry, aby wygospodarowała odpowiednią ilość czasu, pozwalającą na poświęcenie studentom większej uwagi. 


\section{Podsumowanie}

Zastosowanie eseju jest jednym z elementów ukazujących różnice między polskim a brytyjskim systemem edukacji. W tym drugim, jak, mam nadzieję, udało mi się pokazać, na przykładzie LSE, jest on wszechstronnie wykorzystywany w procesach zarówno nabywania, jak i sprawdzania wiedzy. Niedostateczne wykorzystanie eseju w Polsce ma związek z systemowymi problemami polskiej nauki. Dotyczy to m.in. braku możliwości wyboru przedmiotów przez studentów w ramach kierunków, przeciążenia ich zbyt dużą liczbą przedmiotów czy braku dedykowanego wsparcia w zakresie tworzenia prac pisemnych na poziomie akademickim oraz niewystarczającej ilości czasu umożliwiającej dogłębne ich sprawdzenie przez wykładowców. W związku z tym w bardzo bezpośredni sposób są formułowane obawy: „Czy w ogóle i w jaki sposób oceniać język pisemnych wypowiedzi studentów, skoro nie podlega on formalnemu kształceniu ani też doskonaleniu w ramach studiów" (Kaliszewska, 2010, s. 140).

Wśród wymienionych powodów, dla których rozpowszechnienie eseju w Polsce nie będzie łatwe, chcę zwrócić uwagę na dwa, odróżniające nasz system edukacji od brytyjskiego i wpływające na stosunek studentów do tego typu prac. Mam na myśli liczbę przedmiotów oraz możliwość ich wyboru. Z jednej strony, polscy studenci mają do zaliczenia większą liczbę przedmiotów niż słuchacze w Wielkiej Brytanii. $Z$ drugiej zaś w zdecydowanej większości są pozbawieni możliwości wyboru tychże przedmiotów, a jedyny wybór, jakiego dokonują, to kierunek (studia licencjackie) bądź specjalizacja (studia magisterskie). W efekcie tracą osoby, które na uczelni znalazły się nieprzypadkowo i mają sprecyzowaną wizję swojego rozwoju. Są one bowiem zmuszone do przyswajania wiedzy, która, chociaż pochodzi z interesującej je dyscypliny, w ogóle nie trafia w ich zainteresowania.

Zasadniczą konsekwencją kombinacji dwóch wspomnianych powodów jest mniejsza ilość czasu, jaką student może przeznaczyć na pogłębianie wiedzy na temat tego, do czego rzeczywiście czuje powołanie, zaś w ostateczności może to być utrata zainteresowania przedmiotem studiów. Zatem, z praktycznego punktu widzenia, takie przeciążenie polskich studentów powoduje, że nie mogą oni poświęcić wystarczająco dużo czasu na tworzenie wysokiej jakości prac pisemnych. W tym kontekście mniejsze ogólne obciążenie słuchaczy studiów na LSE, a zdecydowanie większe w zakresie wybranej specjalizacji pozwala jednocześnie stworzyć absolwenta mającego ogólne kompetencje poszukiwania i przetwarzania informacji oraz lepiej dostosowanego do konkretnego rynku pracy.

Wydaje się, że zarówno polski system edukacji wyższej, jak i społeczeństwo dużo zyskałoby na rozpowszechnieniu tej formy nauczania, ze względu na 
umiejętności, jakie rozwija. Po pierwsze, w świecie XXI w. umysł ludzki nie powinien być już zmuszany do zapamiętywania informacji, jest ich bowiem zbyt wiele, a co więcej - ich liczba szybko rośnie. Po drugie, narzędzia cyfrowe radzą sobie z zapisem i przetwarzaniem informacji o wiele lepiej niż przeciętny, choćby najlepiej wykształcony, człowiek. Kluczowa zaś staje się umiejętność szybkiego, a przy tym sprecyzowanego sposobu formułowania własnych (patrz innowacyjna gospodarka) myśli na podstawie danych. Pisanie esejów może być jednym ze sposobów na odejście od XIX-wiecznego sposobu egzaminowania i nauczania opartego na zapamiętywaniu informacji na rzecz XXI-wiecznej kreatywności i samodzielnego myślenia.

\section{Bibliografia}

Andrews, R. (2003). The End of the Essay? Teaching in Higher Education, 8(1), 117-128. Gramer, R. (2015). The Best International Relations Schools in the World. Foreign Policy. https://foreignpolicy.com/2015/02/03/top-twenty-five-schools-international-relations/ (29.03.2017).

Kaczmarczyk, A. (2012). Wywiad z prof. Grażyną Habrajską. Rozmowa dnia - 30 lipca 2012. Stowarzyszenie Dziennikarzy Polskich. http://www.sdp.pl/wywiady /1866,rozmowa-dnia-30-lipca-2012,1343614164 (27.03.2017).

Kaliszewska, M. (2010). Bogacenie warsztatu pedagoga o esej. Studia Pedagogiczne. Problemy Społeczne, Edukacyjne i Artystyczne, 19, 123-144.

Lawson, G. (2015). Theories of International Relations 2015-16. https://www.academia.edu/8451197/Theories_of_International_Relations_2015-16 (14.03.2017).

LSE (2016a). EH472 Essay in Quantitative Economic History. LSE Course Guides. http:// www.lse.ac.uk/resources/calendar/courseGuides/EH/2016_EH472.htm (14.03.2017).

LSE (2016b). EH483 The Development and Integration of the World Economy in the 19th and 20th Centuries. LSE Course Guides. http://www.lse.ac.uk/resources/calendar/courseGuides/EH/2016_EH483.htm (14.03.2017).

LSE (2016c). IR416 The EU in the World. LSE Course Guides. http://www.lse.ac.uk/ resources/calendar/courseGuides/IR/2016_IR416.htm (15.03.2017).

LSE (2016d). IR443 Strategy in a Changing World. LSE Course Guides. http://www.lse. ac.uk/resources/calendar/courseGuides/IR/2016_IR443.htm (15.03.2017).

LSE (2016e). LN991 Academic Writing Skills. LSE Course Guides. http://www.lse.ac.uk/ resources/calendar/courseGuides/LN/2016_LN991.htm (4.01.2017).

LSE (2016f). LN995 Academic Writing Skills. LSE Course Guides. http://www.lse.ac.uk/ resources/calendar/courseGuides/LN/2016_LN995.htm (28.03.2017). 
LSE (2016g). MG404 Behavioural Fundamentals for Marketing and Management. LSE Course Guides. http://www.lse.ac.uk/resources/calendar/courseGuides/MG/2016_ MG404.htm (15.03.2017).

LSE (2016h). MG411 Firms and Markets. LSE Course Guides. http://www.lse.ac.uk/ resources/calendar/courseGuides/MG/2016_MG411.htm (15.03.2017).

LSE (2016i). MG417 Extended Essay. LSE Course Guides. http://www.lse.ac.uk/resources/calendar2017-2018/courseGuides/MG/2016_MG417.htm (14.03.2017).

LSE (2016j). MG425 Global Business Management. LSE Course Guides. http://www. lse.ac.uk/resources/calendar/courseGuides/MG/2016_MG425.htm (15.03.2017). LSE (2016k). SA465 Criminal Justice Policy-Long Essay. LSE Course Guides. http://www. lse.ac.uk/resources/calendar/courseGuides/SA/2016_SA465.htm (14.03.2017).

LSE (20161). SA466 European and Comparative Social Policy - Long Essay. LSE Course Guides. http://www.lse.ac.uk/resources/calendar/courseGuides/SA/2016_SA466. htm (14.03.2017).

LSE (2016m). SA471 Social Policy and Planning - Long Essay. LSE Course Guides. http://www.lse.ac.uk/resources/calendar/courseGuides/SA/2016_SA471. htm (14.03.2017).

LSE (2016n). SA4C1 Long Essay and the Research Process. LSE Course Guides. http:// www.lse.ac.uk/resources/calendar/courseGuides/SA/2016_SA4C1.htm (14.03.2017).

Maciejowska, I. (2009). Pisanie esejów jako metoda kształcenia studentów ochrony środowiska. Chemistry - Didactics - Ecology - Metrology, 14(1-2), 95-100.

Norton, L.S. (1990). Essay-writing: What really counts? Higher Education, 20(4), 411-442.

Przybyłowska, I., Krzewińska, A. (2012). Patologiczne zachowania studentów związane ze studiowaniem. W: J. Zamecka (red.), Normy, dewiacje i kontrola społeczna. Warszawa: IPSiR UW, 313-337.

Sieńczyło-Chlabicz, J. (2010). Odpowiedzialność nauczycieli akademickich, doktorantów i studentów z tytułu popełnienia plagiatu. Transformacje Prawa Prywatnego, 1, 133-158.

Słowik, P. (2016). Sędziowie nie potrafią pisać. Dlatego nie rozumiemy orzeczeń. gazetaprawna.pl. http://prawo.gazetaprawna.pl/artykuly/948858,sedziowie-nie-pot rafia-pisac-dlatego-nie-rozumiemy-orzeczen.html (23.03.2017).

SMG/KRC Poland Media S.A. (2010). Analiza zasobów kadrowych w uczelniach na poszczególnych kierunkach i wypracowanie zasad etatyzacji. Raport końcowy. Warszawa.

The Complete University Guide (2017). Top UK University League Tables and Rankings 2017 - Complete University Guide. https://www.thecompleteuniversityguide. co.uk/league-tables/rankings?o=Student-Staff+Ratio (28.03.2017).

Womack, P. (1993). What Are Essays for? English in Education, 27(272), 42-48. 


\section{Summary}

\section{Academic Essay as the Basic Form of Student's Expression} - Differences between British and Polish Higher Education Systems in Relation to Short Pieces of Written Work

Service-based modern economy requires from workers to have good communication skills, not only spoken, but also written. However, in the Polish higher education system this issue, except of theses, does not gain much attention. In contrast, essay is one of the main tools of teaching and assessment in British academia. This paper presents how essay writing is used at the London School of Economics. Afterwards the author enters into a polemic with Polish scholars who articulate problems related to its wider use in Poland and suggests few ideas of how these challenges can be addressed.

Keywords: essay writing, teaching methods, development of writing, higher education

\section{Mgr Maciej Hacaga}

Doktorant w Akademii Sztuki Wojennej. Absolwent studiów magisterskich $\mathrm{w}$ London School of Economics and Political Science i na Uniwersytecie Wiedeńskim. Członek Zespołu Młodych przy Komitecie Prognoz PAN. 